\title{
Lymphocytic meningoencephalomyelitis associated with Myxobolus sp. (Bivalvulidae: Myxozoa) infection in the Amazonian fish Eigenmannia sp. (Sternopygidae: Gymnotiformes)
}

Meningoencefalomielite linfocitária associada à infecção por Myxobolus sp. (Bivalvulidae:Myxozoa) em peixe amazônico Eigenmannia sp. (Şternopygidae: Gymnotiformes)

\author{
José Ledamir Sindeaux Neto ${ }^{1}$; Michele Velasco ${ }^{1}$; José Mauro Vianna da Silva ${ }^{1}$; Patricia de Fátima Saco dos Santos ${ }^{1}$; \\ Osimar Sanches ${ }^{2}$; Patricia Matos ${ }^{3}$; Edilson Matos ${ }^{1 *}$ \\ ${ }^{1}$ Carlos Azevedo Research Laboratory, Universidade Federal Rural da Amazônia - UFRA, Belém, PA, Brasil \\ ${ }^{2}$ Centro de Diagnóstico Veterinário - CDAPVET, Presidente Prudente, SP, Brasil \\ ${ }^{3}$ Edilson Matos Research Laboratory, Universidade Federal do Pará - UFPA, Belém, PA, Brasil
}

Received November 25, 2015

Accepted January 13, 2016

\begin{abstract}
The genus Myxobolus, parasites that infect fishes, which cause myxobolosis, includes spore organisms belonging to the phylum Myxozoa and represents approximately $36 \%$ of all species described for the entire phylum. This study describes lymphocytic meningoencephalomyelitis associated with Myxobolus sp. infection in the brain and spinal cord (the central nervous system, CNS) of Eigenmannia sp., from the Amazon estuary region, in the Administrative District of Outeiro (DAOUT), Belém, Pará, Brazil. In May and June 2015, 40 Eigenmannia sp. specimens were captured from this region and examined. The fish were anesthetized, slaughtered and dissected for sexing (gonad evaluation) and studying parasites and cysts; after diagnosing the presence of the myxozoans using a light microscope, small fragments of the brain and spinal cord were removed for histological processing and Hematoxylin-Eosin and Ziehl-Neelsen staining. Histopathological analysis of the brain and spinal cord, based on histological sections stained with Hematoxylin-Eosin, pronounced and diffuse edema in these tissues, and congestion, degeneration, and focal necrosis of the cerebral cortex. The present study describes lymphocytic meningoencephalomyelitis associated with infection by Myxobolus sp. in the central nervous system of Eigenmannia sp.
\end{abstract}

Keywords: Knifefish, Amazonia, myxosporean, histopathology, microscopy, nervous-system.

\section{Resumo}

O gênero Myxobolus é composto por parasitas esporais que podem infectar peixes e causar a "myxobolose". São organismos pertencentes ao filo Myxozoa e representam cerca de 36\% do total de espécies descritas para todo o Filo. Este estudo descreve meningoencefalomielite linfocitária, associada à infecção por Myxobolus sp. no cérebro e medula espinhal (SNC) de Eigenmannia sp, oriundo de regiáo estuarina amazônica, no Distrito Administrativo de Outeiro (DAOUT), município de Belém, Pará, Brasil. Foram capturados e examinados 40 espécimes de Eigenmannia sp. entre os meses de maio e junho de 2015. Os peixes foram anestesiados, abatidos e dissecados para sexagem (avaliação das gônadas) e pesquisa de parasitos e cistos. Após o diagnóstico da presença dos mixosporidios, utilizando-se microscópio de luz, pequenos fragmentos do cérebro e da medula espinal foram removidos para processamento histológico e coloração por Hematoxilina-Eosina e coloração especial em Ziehl-Neelsen. A análise histopatológica do cérebro e da medula espinhal, com base em cortes histológicos corados com Hematoxilina-Eosina, mostrou edema difuso nesses tecidos, e congestão, degeneraçáo e necrose focal do córtex cerebral. O presente estudo descreve meningoencefalomielite linfocítica, associada à infecção por Myxobolus sp., no sistema nervoso central de Eigenmannia sp.

Palavras-chave: Ituí, Amazônia, mixosporidios, histopatologia, microscopia, sistema-nervoso.

*Corresponding author: Edilson Matos. Avenida Presidente Tancredo Neves,

2501, Montese, CEP 66077-901, Belém, PA, Brasil.

e-mail: edilson.matos9@gmail.com. 


\section{Introduction}

Fishes of the genus Eigenmannia (Order Gymnotiformes), have a serpentiform morphology and neotropical distribution (ALBERT, 2001) and are commonly known as "knifefishes" due to their long and slender bodies, which have undulatory movement, directly linked to their long anal fins (CAMPOS-DA-PAZ \& ALBERT, 1998). Another important characteristic of these fishes is that they continously emit low-voltage electric discharges (KRAMER, 1999; ALVES-GOMES, 2001).

In their natural habitat, fishes can be infected by various parasites, even without showing clinical signs of parasitosis. However, when environmental changes occur due to anthropogenic action or natural reasons (which interfere with immunity), these fishes begin to show clinical signs of certain diseases that can vary from a reduction in body size to the death of the host (DEAN et al. 2001; PAVANELLI et al., 2002).

Among the parasites that infect fishes, we highlighted the genus Myxobolus, which causes myxobolosis (MOLNÁR \& BÉKÉSI, 1992). They are parasitic spore organisms belonging to the phylum Myxozoa, having approximately 800 described species, which is equivalent to approximately $36 \%$ of all species described for the entire phylum (LOM \& DYKOÁ, 2006). They have two valves, a criterion that classifies them in the order Bivalvulida, and their morphology comprises an ellipsoid body, two polar capsules, and a sporoplasm with binucleate cells, usually spherical and sometimes containing a polysaccharide inclusion (KENT et al., 2001; LOM \& DYKOÁ, 2002, 2006).

M. cerebralis is the most studied Myxozoa, responsible for causing central nervous system (CNS) disease in fishes, the principal symptom of which is that infected fish swim in circles, thus giving it the name "whirling disease" (GILBERT \& GRANATH, 2001).

Several other species of Myxobolus infect the CNS, as is the case for $M$. inaequus (KENT \& HOFFMAN 1984), M. neurophilus, Guilford, 1963 (DZULINKSY et al., 1994), M. encephalicus, Mulsow, 1911, (ANTYCHOWICZ \& REICHERT, 2005), and Myxobolus sp. (FERGUSON et al., 2011).

The present study describes lymphocytic meningoencephalomyelitis associated with infection by Myxobolus sp. in the brain and spinal cord (CNS) of Eigenmannia sp. from the Amazon estuary region, in the Administrative District of Outeiro (DAOUT), Belém, Pará, Brazil.

\section{Materials and Methods}

In May and June 2015, 40 Eigenmannia sp. specimens were captured from the Amazon estuary region, in the Administrative District of Outeiro-DAOUT ( $1^{\circ} 14^{\prime}$ S; $\left.48^{\circ} 26^{\prime} \mathrm{W}\right)$, Belém, Pará, Brazil, and examined. The specimens were transported live in artificially aerated plastic bags containing water from their habitat to the Carlos Azevedo Research Laboratory at the UFRA-Belém. Here, they were kept in aquaria with water temperature ranging from 28 to $30{ }^{\circ} \mathrm{C}$. The fish were anesthetized with tricaine methanesulfonate (MS222,) at a concentration of $50 \mathrm{mg} \cdot \mathrm{L}^{-1}$, the animal was anesthetized, slaughtered and dissected to evaluate the gonads (sexing) and analyze the parasites and cysts using a stereo microscope (ethics committee on animal use no 013/2014 - UFRA).
After determining the presence of cysts in the brain and spinal cord, small fragments of the organs were removed for observation under light microscopy (LM), pressed between a slide and coverslip, and analyzed to determine the presence of parasites. Images were captured using a Zeiss AxiocaCAm Erc 5 camera, appropriately coupled to a Zeiss Primo Star microscope, to measure the spores using AxioVision LE software. After diagnosing the presence of the myxosporids, small samples of the infected organs (approximately $0.5 \mathrm{~cm}$ thick) were removed, fixed in Davidson solution (neutral buffered formalin, glacial acetic acid, 95\% ethanol alcohol, and distilled water) for $24 \mathrm{~h}$. Samples were then processed using the paraffin embedding method, and $5 \mu \mathrm{m}$-thick sections were stained with Hematoxylin-Eosin and Ziehl-Neelsen (LUNA, 1968).

\section{Results and Discussion}

Necropsy of the Eigenmannia sp. specimens enabled us to study the parasites and sex the animals; 70\% (28/40) of the specimens were infected by Myxobolus sp. in the brain and spinal cord. $60 \%(24 / 40)$ of the fish evaluated were male and $40 \%$ $(16 / 40)$ were female.

More specific prevalence data demonstrated that of the 28 infected animals, 16 were male and 12 were female; $66 \%$ of the males and $75 \%$ of the females exhibited infection symptomatic of Myxobolus sp., revealing potential differences in infections for males and females. Adriano et al. (2012) found no difference between males and female in the prevalence of infection by Myxobolidae in Zungaro jahu, a fish from the Mato Grosso Pantanal, Brazil.

The spores exhibited morphological characteristics of the genus Myxobolus, according to descriptions by Lom \& Dykoá (2006), with ellipsoid bodies, two asymmetrical polar capsules (Figures 1, 2 and 3), similar to those described by Kent \& Hoffman (1984), Cellere et al. (2002) for M. inaequus in E. virescens and M. absonus in Pimelodus maculatus and Azevedo et al. (2002) for $M$. desaequalis in Apteronotus albifrons respectively.

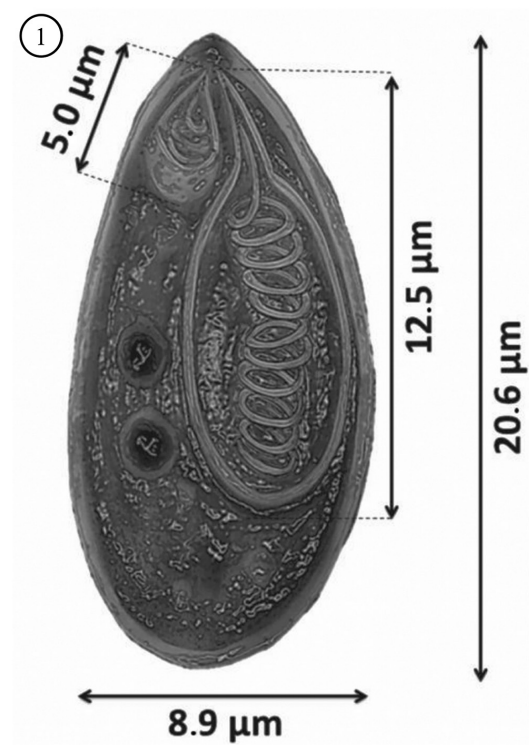

Figure 1. Myxobolus sp. in semi-schematic drawing of a valvar view of the spore of the myxosporean parasite from the nervous system. 

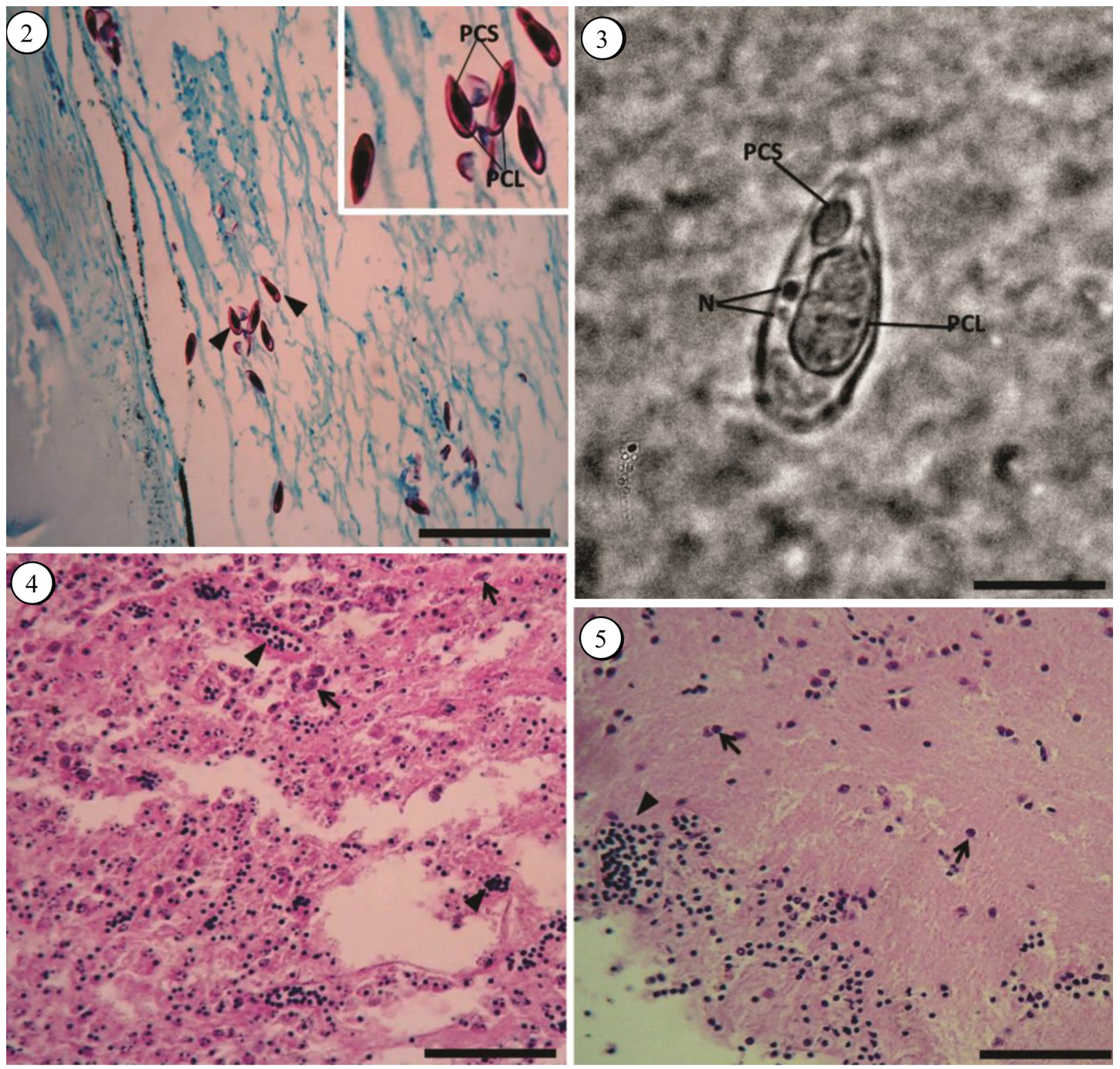

Figure 2. Spinal cord histological section stained in Ziehl-Neelsen, showing spore cluster (arrowhead) in the subarachnoid space of the spinal cord, highlighting spores (inset) with large polar capsules (LPC) and small polar capsules (SPC) Scale bar: $80 \mu \mathrm{m}$. Figure 3. Myxobolus sp. spore, with large polar capsule (LPC) and small polar capsule (SPC), with the presence of nuclei (n) in the lateral space below the smaller polar capsule $10 \mu \mathrm{m}$. Figures 4 and 5. Photomicrograph of brain histological sections stained in Hematoxylin and Eosin, 4. Inflammatory infiltrate agglomerations (arrowhead), with the presence of astrocytes (arrow). Scale bar: $310 \mu \mathrm{m}$. 5. Pyramidal layer, highlighting inflammatory infiltrate agglomerations (arrowhead) and pyramidal neurons (arrow). Scale bar: $300 \mu \mathrm{m}$.

Results of the measurements of length (L) and width (W) of the spores and polar capsules and morphometric comparisons with other Myxobolus spp. with different capsules are shown in Table 1.

We found a correlation between the fish cells and parasitic spores via the hematoxylin-eosin (HE) histological technique (Figures 4 and 5), which was used by Molnár \& Baska (1999) to redescribe $M$. hungaricus, Jaczó 1940, in Abramis brama.

Ziehl-Neelsen staining, used in the histopathological analyses, highlighted the polar capsules of the spores to identify spores with asymmetrical polar capsules dispersed throughout the nervous tissue (Figure 2); Kaur \& Singh (2009) used a similar histological technique to highlight the polar capsules of $M$. eirasi in Cirrhina mrigala.

Histopathological analysis of the brain and spinal cord, based on histological sections stained with Hematoxylin-Eosin, allowed us to analyze pronounced and diffuse edema in these tissues, and congestion, degeneration, and focal necrosis of the cerebral cortex. In the cerebral cortex, there was also gliosis and marked satellitosis, a focal area of malacia, and marked lymphocytic inflammatory infiltrate in the brain parenchyma and meninges (Figures 4 and 5). We also observed a pronounced quantity of Myxobolus sp. spores forming cysts dispersed throughout the spinal cord. There was marked edema, malacia, and moderate lymphocytic inflammatory infiltrate in the brain and spinal cord (the central nervous system, CNS) associated with the area of parasitism in the spinal cord (Figure 2). Using histopathological analysis, Campos et al. (2008) noted large quantities of inflammatory infiltrate caused by Myxobolus sp. infection, showing that parasites of this genus are able to cause inflammatory immune responses in their host. 
Table 1. Comparison of measurements of spores of Myxobolus sp. LS, total length of the spore; WS, width of the spore; PC, polar capsules (length $\mathrm{x}$ width). All measurements are provided in micrometers.

\begin{tabular}{lcccc}
\hline & $\begin{array}{c}\text { Myxobolus inaequus } \\
\text { Kent \& Hoffman (1984) }\end{array}$ & $\begin{array}{c}\text { Myxobolus absonus } \\
\text { Cellere et al. (2002) }\end{array}$ & $\begin{array}{c}\text { Myxobolus desaequalis } \\
\text { Azevedo et al. (2002) }\end{array}$ & $\begin{array}{c}\text { Myxobolus sp. } \\
\text { Present study }\end{array}$ \\
\hline Host & Eigenmannia virescens & Pimelodus maculatus & Apteronotus albifrons & Eigenmannia sp. \\
Site of infection & Brain & Opercular cavity & Brânquias & Brain \\
LS & 19.8 & 15.7 & 18.3 & 20.6 \\
WS & 8.6 & 10.2 & 8.6 & 8.9 \\
Larger PC & $11.8 \times 3.6$ & $6.4 \times 3.6$ & $11.2 \times 4.9$ & $12.5 \times 5.7$ \\
Smaller PC & $4.8 \times-14.6 \times 2.5$ & $11-12$ & $5.0 \times 2.65$ \\
Larger capsule PFC & 14 & 5 & $4-5$ & 11 \\
Smaller capsule PFC & 6 & 3 & Brazil & 3 \\
Country & South America & South America & Brazil \\
\hline
\end{tabular}

The findings described in the present study enabled us to characterize a CNS infection in Eigenmannia sp. caused by spores of the genus Myxobolus, where histopathology characterized lymphocytic meningoencephalomyelitis of the brain and spinal cord. It is important to note that no clinical sign of disease was observed in the host. Studies of this nature are fundamental for understanding myxobolosis in the nervous system of Amazonian fish.

\section{Acknowledgements}

We are grateful to CAPES (Coordenação de Aperfeiçoamento de Pessoal de Nível Superior), CNPq (Conselho Nacional de Desenvolvimento Científico e Tecnológico), FAPESPA (Fundação Amazônia de Amparo a Estudos e Pesquisas do Pará), SISBIO/ICMBio-IBAMA (Instituto Brasileiro do Meio Ambiente e dos Recursos Naturais Renováveis), Licence no 27119 (Brazil); The Edilson Matos Research Laboratory (LPEM-UFPA).

\section{References}

Adriano EA, Ceccarelli PS, Silva MRM, Maia AAM. Prevalência, distribuição geográica e sazonal de protozoários e mixozoários parasitos de jaú (Zungaro jahu) no Pantanal Matogrossense. Pesq Vet Bras 2012; 32(12): 1341-1344. http://dx.doi.org/10.1590/S0100-736X2012001200020.

Albert JS. Species diversity and phylogenetic systematics of American knifefishes (Gymnotiformes, Teleostei). Misc Pub, Museum of Zoology. University of Michigan 2001; 190: 1-127.

Alves-Gomes JA. The evolution of electroreception and bioelectrogenesis in teleost fish: a phylogenetic perspective. J Fish Biol 2001; 58(6): 14891511. http://dx.doi.org/10.1111/j.1095-8649.2001.tb02307.x.

Antychowicz J, Reichert M. Occurrence of Myxobolus encephalicus (Mulsow 1911) in Poland: possible relationship between the parasite infection and clinical symptoms in common carp (Cyprinus carpio). Bull Vet Inst Pulawy 2005; 49(1): 35-39.

Azevedo C, Corral L, Matos E. Myxobolus desaequalis n. sp. (Myxozoa, Myxosporea), parasite of the Amazonian freshwater fish, Apteronotus albifrons (Teleostei, Apteronotidae). J Eukaryot Microbiol 2002; 49(6): 485-488. http://dx.doi.org/10.1111/j.1550-7408.2002.tb00233.x. PMid:12503685.

Campos CM, Moraes JRE, Moraes FR. Histopatologia de fígado, rim e baço de Piaractus mesopotamicus, Prochilodus lineatus e Pseudoplatystoma fasciatum, parasitados por mixosporidios, capturados no rio Aquidauana, Mato Grosso do Sul, Brasil. Rev Bras Parasitol Vet 2008; 17(4): 200-205. PMid:19265578.

Campos-da-Paz R, Albert JS. The gymnotiform 'eels' of tropical America: a history of classification and phylogenetic studies of South American electric knifefishes (Teleostei: Ostariophysi). In: Malabarba L, Reis RE, Vari RP, Lucena CAS, Lucena ZMS, editors. Phylogeny and Classification of Neotropical Fishes. Porto Alegre: Edpucrs; 1998. p. 419-446.

Cellere EF, Cordeiro NS, Adriano EA. Myxobolus absonus sp. n. (Myxozoa: Myxosporea) Parasitizing Pimelodus maculatus (Siluriformes: Pimelodidae), a South American Freshwater Fish. Mem Inst Oswaldo Cruz 2002; 97(1): 79-80. http://dx.doi.org/10.1590/S0074-02762002000100012. PMid:11992152.

Dean JH, House RV, Luster MI. Immunotoxicology: effects of, and responses to drugs and chemicals. In: Hayes AW, editor. Principles and methods of toxicology. 4th ed. Philadelphia: CRC Press; 2001. p. 1415-1450.

Dzulinksy K, Cone DK, Faulkner GT, Cusack R. Development of Myxobolus neurophilus (Guilford, 1963) (Myxosporea) in the brain of yellow perch (Perca flavescens) in Vinegar Lake, Nova Scotia. Can J Zool 1994; 72(7): 1180-1185. http://dx.doi.org/10.1139/z94-158.

Ferguson JA, St-Hilaire S, Peterson TS, Rodnick KJ, Kent ML. Survey of parasites in threatened stocks of coho salmon (Oncorhynchus kisutch) in Oregon by examination of wet tissues and histology. J Parasitol 2011; 97(6): 1085-1098. http://dx.doi.org/10.1645/GE-2757.1. PMid:21668345.

Gilbert MA, Granath WO Jr. Persistent infection of Myxobolus cerebralis, the causative agent of salmonid whirling disease, in Tubifex tubifex. J Parasitol 2001; 87(1): 101-107. http://dx.doi.org/10.1645/00223395(2001)087[0101:PIOMCT]2.0.CO;2. PMid:11227872.

Kaur H, Singh R. A new myxosporean species, Myxobolus eirasi sp. nov. and a known species M. venkateshi Seenappa and Manohar, 1981 from the Indian major carp fish Cirrhina mrigala (Ham.). Protistology 2009; 6(2): 126-130.

Kent ML, Andree KB, Bartholomew JL, El-Matbouli M, Desser SS, Devlin RH, et al. Recent Advances in Our Knowledge of the Myxozoa. J Eukaryot Microbiol 2001; 48(4): 395-413. http://dx.doi. org/10.1111/j.1550-7408.2001.tb00173.x. PMid:11456316.

Kent ML, Hoffman GL. Two new species of Myxozoa, Myxobolus inaequus sp. n. and Henneguya theca sp. n. from the brain of a South American knife fish, Eigenmannia virescens (V.). J Protozool 1984; 31(1): 91-94. http://dx.doi.org/10.1111/j.1550-7408.1984.tb04295.x. PMid:6737321. 
Kramer B. Mechanisms of signal analysis in Eigenmannia (Gymnotiformes): the jamming avoidance response and communication. In: Val AL, Almeida-Val VMF, editors. Biology of tropical fishes. Manaus: Instituto Nacional de Pesquisas da Amazônia; 1999. p. 41-62.

Lom J, Dykoá I. Myxozoan genera: definition and notes on taxonomy, life-cycle terminology and pathogenic species. Folia Parasitol (Praha) 2006; 53(1): 1-36. http://dx.doi.org/10.14411/fp.2006.001. PMid:16696428.

Lom J, Dykoá I. Ultrastructure of Nucleospora secunda n. sp. (Microsporidia), parasite of enterocytes of Nothobranchius rubripinnis. Eur J Protistol 2002; 38(1): 19-27. http://dx.doi.org/10.1078/0932-4739-00844.

Luna LG. Manual of histologic staining methods of the armed forces institute of pathology. 3rd ed. New York: MacGraw-Hill Book Company; 1968.
Molnár K, Baska F. Redescription of Myxobolus hungaricus Jaczó, 1940 (Myxosporea: Myxobolidae), a parasite of bream (Abramis brama). Acta Vet Hung 1999; 47(3): 341-349. http://dx.doi.org/10.1556/AVet.47.1999.3.8. PMid:10497828.

Molnár K, Békési L. Description of a new Myxobolus species, M. colossomatis $\mathrm{n}$. sp. from the teleost Colossoma macropomum of the Amazon River basin. J Appl Ichthyol 1992; 9(1): 57-63. http://dx.doi. org/10.1111/j.1439-0426.1993.tb00388.x.

Pavanelli GC, Eiras JC, Takemoto RM. Doenças de peixes: profilaxia, diagnóstico e tratamento. Maringá: Editora Universidade Estadual de Maringá; 2002. 305 p. 